\title{
PENGARUH PENERAPAN METODE TUTOR SEBAYA TERHADAP KEMAMPUAN PEMECAHAN MASALAH MATEMATIS BERDASARKAN KEMAMPUAN AWAL MATEMATIS
}

\section{EFFECT OF APPLICATION OF PEER TUTOR METHODS ON MATHEMATICAL PROBLEM SOLVING ABILITY BASED ON EARLY MATHEMATICAL CAPABILITIES}

\author{
Tuvi Noryanti, Zubaidah Amir MZ, Hayatun Nufus \\ Pendidikan Matematika, FTK Universitas Islam Negeri Sultan Syarif Kasim Riau, Pekanbaru \\ Email: zubaidah.amir@uin-suska.ac.id; hayatun.nufus@uin-suska.ac.id
}

Diterima: 04 Maret 2019, Disetujui: 24 September 2019, Diterbitkan: 30 September 2019

\begin{abstract}
Abstrak: Tujuan penelitian ini adalah untuk mengetahui pengaruh kemampuan pemecahan masalah matematis menggunakan penerapan metode tutor sebaya dengan siswa yang belajar menggunakan pembelajaran langsung terhadap kemampuan awal matematis pada siswa kelas VII SMP Negeri 32 Pekanbaru. Penelitian ini merupakan penelitian Quasi Eksperimen. Teknik pengumpulan data menggunakan teknik tes, teknik observasi, dan dokumentasi. Untuk melihat hasil penelitian tersebut digunakan rumus uji-t (test-t) untuk mengetahui hasil penelitian dan anova dua jalur. Berdasarkan hasil analisis data, didapat kesimpulan bahwa: (1) Terdapat perbedaan kemampuan pemecahan masalah matematis antara siswa yang mengikuti pembelajaran metode tutor sebaya dengan siswa yang mengikuti pembelajaran langsung, (2) Terdapat perbedaan kemampuan pemecahan masalah matematis antara siswa yang mengikuti pembelajaran metode tutor sebaya dengan siswa yang mengikuti pembelajaran langsung jika ditinjau dari kemampuan awal matematis.
\end{abstract}

Kata Kunci : Metode Tutor Sebaya, Kemampuan Pemecahan Masalah Matematis, Kemampuan Awal Matematis

Abstract: The purpose of this study was to determine the effect of mathematical problem solving abilities using the application of peer tutoring methods with students who learn to use direct learning to mathematical initial abilities in class VII Pekanbaru 32 Junior High School. This research is a Quasi Experiment research. Data collection techniques use test techniques, observation techniques, and documentation. Based on the results of data analysis, it can be concluded that: (1) There are differences in mathematical problem solving abilities between students who take learning peer tutoring methods with students who follow direct learning, (2) There are differences in mathematical problem solving abilities between students who take learning peer tutoring methods with students who follow direct learning when viewed from the initial mathematical abilities.

Keywords: Peer Tutor Method, Mathematical Problem Solving Ability, Mathematical Initial Ability

\section{PENDAHULUAN}

Salah satu bidang ilmu pengetahuan yang sangat penting adalah matematika. Pada dasarnya kemampuan pemecahan masalah matematis merupakan satu kemampuan matematis yang penting dan perlu dikuasai oleh siswa yang belajar matematika [1]. Apabila seorang siswa dilatih untuk menyelesaikan masalah, maka siswa akan mampu mengambil keputusan sebab siswa bisa mempunyai keterampilan tentang bagaimana mengumpulkan informasi yang relevan, menganalisis informasi dan menyadari betapa perlunya meneliti kembali hasil yang telah diperolehnya [2].

Masalah dalam matematika adalah mata pelajaran yang siswa sendiri dapat menyelesaikan tanpa menggunakan metode atau algoritma rutin[3]. Dalam pemecahan masalah, dengan sekelompok kecil siswa memberikan siswa dengan berbagai strategi pemecahan masalah (heuristik), dan kemudian melatih mereka untuk menggunakan strategi-strategi efektif[4]. Standar proses dalam pembelajaran matematis yang pertama yaitu belajar untuk memecahkan masalah[5]. Berdasarkan standar proses yang telah dikemukakan, kemampuan pemecahan masalah matematis memegang peranan penting karena selain sebagai tuntutan pembelajaran matematika juga bermanfaat bagi siswa dalam kehidupan sehari-hari.

Menurut Polya dalam pemecahan suatu masalah terdapat empat langkah yang harus dilakukan yaitu: (a) Memahami masalah; (b) Merencanakan pemecahannya; (c) Menyelesaikan masalah sesuai rencana langkah kedua; (d) Memeriksa kembali hasil yang diperoleh [6]. Ada tiga kriteria pengelompokkan kemampuan pemecahan masalah matematis yaitu kriteria tinggi, sedang, dan rendah [7].

Ketika siswa bertindak sebagai "tutor", proses perencanaan apa yang akan mereka mengajar, menyebabkan belajar mandiri dan memperjelas materi pembelajaran [3]. Menurut Dedi Supriyadi, tutor sebaya adalah seorang atau beberapa orang siswa yang ditunjuk dan ditugaskan untuk membantu siswa yang mengalami kesulitan dalam belajar[8]. Metode tutor sebaya adalah suatu metode pendekatan yang dilakukan dengan cara memberdayakan siswa yang 
memiliki daya serap yang tinggi dari kelompok siswa itu sendiri untuk menjadi tutor bagi teman-temannya [9].

Siapapun yang menjadi tutor ada beberapa yang perlu diperhatikan diantaranya (a) Dapat diterima (disetujui) oleh siswa yang mendapat program perbaikan sehingga siswa tidak mempunyai rasa takut atau enggan untuk bertanya kepadanya; (b) Dapat menerangkan bahan pembelajaran yang diperlukan oleh siswa yang menerima program perbaikan; (c) Tidak tinggi hati, kejam atau keras hati terhadap sesama kawan; (d) Mempunyai daya kreativitas yang cukup untuk memberikan bimbingan, yaitu dapat menerangkan pelajaran kepada temannya [10].

Pengaruh metode tutor sebaya pada kegiatan belajar mengajar dapat berjalan secara efektif serta efisien, apabila seorang guru memperhatikan serta melaksanakan beberapa langkah penyelenggaraan metode tutor sebaya. Langkah-langkah pelaksanaan metode tutor sebaya adalah (a) Bagi siswa menjadi kelompok-kelompok kecil sebanyak segmen materi yang disampaikan; (b) Masing-masing kelompok kecil di beri tugas untuk mempelajari satu topik materi, kemudian mengajarkannya kepada kelompok lain.Topik-topik yang diberikan harus yang saling berhubungan; (c) Minta setiap kelompok menyiapkan strategi untuk menyampaikan materi kepada temanteman sekelas; (d) Buat beberapa saran seperti (menyiapkan media pengajaran yang diperlukan; menggunakan contoh-contoh yang relevan; melibatkan siswa lain dalam proses pembelajaran melalui diskusi, permainan, kuis, dan lain-lain; serta memberi kesempatan kepada yang lain untuk bertanya); (e) Beri mereka waktu yang cukup untuk persiapan, baik di dalam maupun di luar kelas; (f) Setiap kelompok menyampaikan materi sesuai tugas yang telah diberikan; (g) Setelah semua kelompok melaksanakan tugas, beri kesimpulan dan klarifikasi sekiranya ada yang perlu di luruskan dari pemahaman siswa [11].

Kemampuan awal dipandang sebagai keterampilan yang relevan yang dimiliki pada saat akan mulai mengikuti suatu pembelajaran sehingga dapat dikatakan bahwa kemampuan awal merupakan prasyarat yang harus dikuasai siswa sebelum mengikuti suatu kegiatan pembelajaran[12]. Kemampuan awal matematis siswa merupakan kemampuan yang telah dipunyai oleh siswa sebelum siswa mengikuti proses pembelajaran yang akan diajarkan oleh guru. Kemampuan awal matematis disini menggambarkan kesiapan siswa dalam menerima pelajaran selama pembelajaran berlangsung yang telah disampaikan oleh guru tersebut[13]. Untuk mengambil kriteria sebagai penentu tingkat kemampuan awal matematis siswa ada tiga kriteria, yaitu siswa kelompok tinggi, sedang, dan rendah[14].

Berdasarkan permasalahan tersebut, tujuan dalam penelitian ini adalah (1) Untuk menganalisis perbedaan kemampuan pemecahan masalah matematis antara siswa yang mengikuti pembelajaran metode tutor sebaya dengan siswa yang mengikuti metode pembelajaran langsung, (2) Untuk menganalisis perbedaan kemampuan pemecahan masalah matematis antara siswa yang mengikuti pembelajaran metode tutor sebaya dengan siswa yang mengikuti metode pembelajaran langsung, jika ditinjau dari kemampuan awal matematis siswa.

\section{METODE PENELITIAN}

Berdasarkan permasalahan dan tujuan yang ingin dicapai telah dikemukakan sebelumnya, maka jenis penelitian yang digunakan peneliti adalah quasi eksperimen, dimana kelompok kontrol tidak dapat berfungsi sepenuhnya untuk mengontrol variabelvariabel luar yang mempengaruhi pelaksanaan eksperimen [15]. Rancangan penelitian yang digunakan peneliti adalah The Nonequivalent PosttestOnly Control Group Design. Adapun paradigma dalam rancangan penelitian ini adalah sebagai berikut:[14].

Tabel 1. Desain Penelitian

\begin{tabular}{ccc}
\hline Kelas & Perlakuan & Posttest \\
\hline Eksperimen & $\mathrm{X}$ & $\mathrm{O}$ \\
Kontrol & - & $\mathrm{O}$ \\
\hline
\end{tabular}

Keterangan:

$\mathrm{X}=$ Perlakuan (Metode Tutor Sebaya);

$\mathrm{O}=$ Posttest (Kemampuan Pemecahan Masalah Matematis)

Tabel 2. Desain Faktorial Penelitian

\begin{tabular}{ccc} 
Kelas & $\begin{array}{c}\text { Metode } \\
\text { Tutor } \\
\text { Sebaya } \\
\left(\mathbf{A}_{1}\right)\end{array}$ & $\begin{array}{c}\text { Pembelajaran } \\
\text { Langsung } \\
\left(\mathrm{A}_{2}\right)\end{array}$ \\
Awal & $\mathrm{A}_{1} \mathrm{~B}_{1}$ & $\mathrm{~A}_{2} \mathrm{~B}_{1}$ \\
Tinggi $\left(\mathrm{B}_{1}\right)$ & $\mathrm{A}_{1} \mathrm{~B}_{2}$ & $\mathrm{~A}_{2} \mathrm{~B}_{2}$ \\
Sedang $\left(\mathrm{B}_{2}\right)$ & $\mathrm{A}_{1} \mathrm{~B}_{3}$ & $\mathrm{~A}_{2} \mathrm{~B}_{3}$ \\
Rendah $\left(\mathrm{B}_{3}\right)$ & & \\
\hline
\end{tabular}

Tempat pelaksanaan penelitian di SMP Negeri 32 Pekanbaru jalan Balam nomor 18 Sukajadi, Pekanbaru. Waktu penelitian ini dilaksanakan tanggal 12 November 2018 sampai 03 Desember 2018 pada semester ganjil tahun ajaran 2018/2019. Populasi dalam penelitian ini adalah seluruh siswa SMP Negeri 32 Pekanbaru. Sedangkan sampel yang digunakan pada penelitian ini adalah siswa kelas VII SMP Negeri 32 Pekanbaru sebanyak dua kelas.

Teknik pengambilan sampel yang digunakan peneliti adalah purposive sampling. Teknik Purposive Sampling adalah teknik penentuan sampel dengan pertimbangan tertentu[14]. Berdasarkan pertimbangan-pertimbangan tertentu, maka kelas terpilihlah kelas VII.5 sebagai kelas eksperimen dan kelas VII.2 sebagai kelas kontrol dengan jumlah peserta didik 23 anak. Metode tutor sebaya sebagai variabel bebas, kemampuan pemecahan masalah matematis sebagai variabel terikat, dan kemampuan 
awal matematis siswa sebagai variabel moderat. Instrumen pengumpulan data adalah soal tes kemampuan awal matematis, soal tes kemampuan pemecahan masalah matematis, lembar observasi aktivitas guru dan siswa. Soal yang diujikan kepada siswa berbentuk uraian dengan jumlah soal lima butir.

Teknik pengumpulan data menggunakan tes, observasi, dan dokumentasi. Tes digunakan untuk mengetahui kemampuan kognitif. Jenis tes yang dilakukan adalah tes kemampuan awal matematis dan posttest. Observasi dilakukan dengan menggunakan lembar pengamatan pada pelaksanaan metode tutor sebaya oleh guru dan siswa selama pembelajaran yang diperoleh melalui lembar observasi. Tujuannya untuk melihat dan memperoleh data yang bisa diukur melalui hasil perhitungan. Dokumentasi yang dilakukan pada penelitian ini adalah untuk mengetahui keadaaan sekolah, kegiatan pembelajaran dalam penelitian serta data lainnya yang dirasa perlu guna menunjang penelitian. Teknik analisis data yang digunakan adalah uji-t (uji perbedaan dua rata-rata), dan uji ANOVA dua jalur.

\section{HASIL PENELITIAN DAN PEMBAHASAN}

Hasil penelitian dengan menggunakan pembelajaran metode tutor sebaya pada kelas eksperimen dan metode pembelajaran langsung pada kelas kontrol. Untuk melihat perbedaan antara kedua kelas bisa dilihat pada hasil data penelitian mengenai mean dan varians kemampuan awal matematis dan kemampuan pemecahan masalah matematis sebagai berikut:

Tabel 3. Mean dan Varians

Kemampuan Awal Matematis

\begin{tabular}{cccccc}
\hline Kelas & Mean & Varians & N & Min & Max \\
\hline Eksperimen & 73,16 & 125,44 & 38 & 52 & 96 \\
Kontrol & 69,37 & 117,29 & 38 & 40 & 88 \\
\hline
\end{tabular}

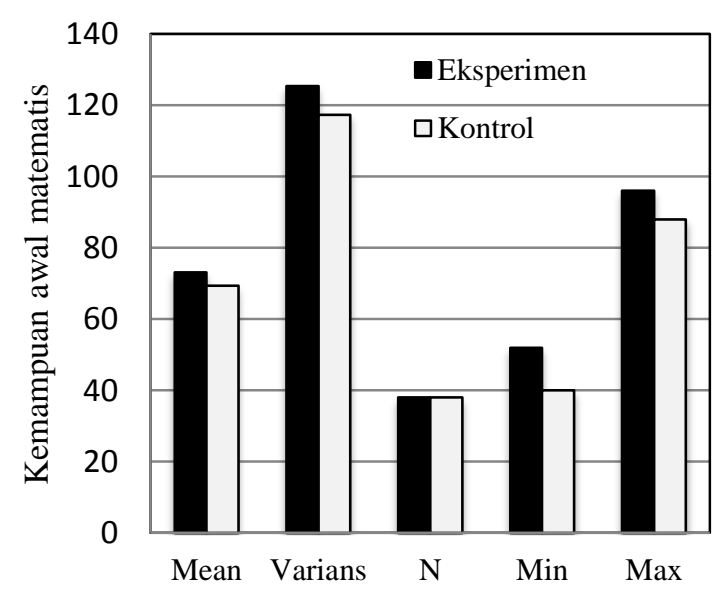

Gambar 1. Mean dan Varians Kemampuan Awal Matematis
Tabel 4. Mean dan Varians Kemampuan Pemecahan Masalah Matematis

\begin{tabular}{cccccc}
\hline Kelas & Mean & Varians & $\mathbf{N}$ & Min & Max \\
\hline Eksperimen & 74,89 & 129,7321 & 38 & 52 & 96 \\
Kontrol & 68,68 & 124,3225 & 38 & 54 & 94 \\
\hline
\end{tabular}

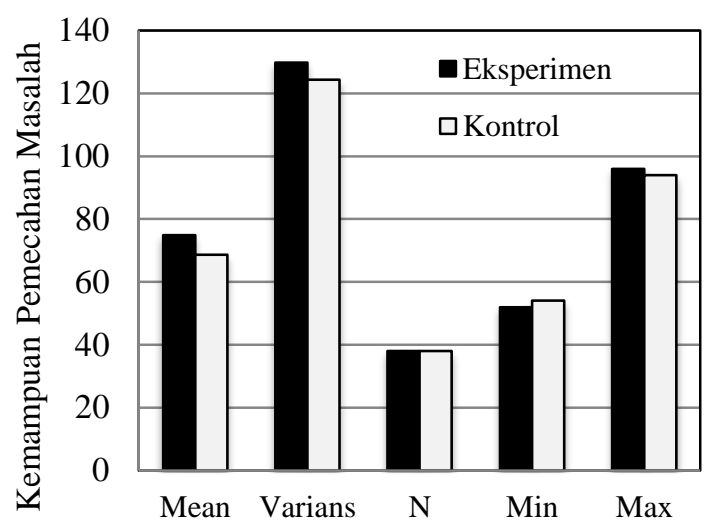

Gambar 2. Mean dan Varians Kemampuan Pemecahan Masalah Matematis

Berdasarkan hasil perhitungan di atas dapat dilihat bahwa nilai rata-rata posttest kelas eksperimen dan kelas kontrol jika dibandingkan rentangnya sedikit berbeda. Untuk perhitungan yang lebih signifikan maka analisis data dilakukan dengan uji-t dan uji ANOVA dua jalur. Penggunaan uji-t dan ANOVA dua jalur harus memenuhi dua syarat yaitu uji normalitas dan homogenitas.

\section{Uji Normalitas Kemampuan Pemecahan Masalah Matematis}

Uji perbedaan kemampuan pemecahan masalah matematis antara siswa mengikuti pembelajaran dengan menggunakan metode tutor sebaya dengan siswa yang mengikuti pembelajaran langsung. Adapun uji normalitas kemampuan pemecahan masalah matematis sesuai dengan tabel 5.

Tabel 5. Uji Normalitas Kemampuan Pemecahan Masalah Matematis

\begin{tabular}{cccc}
\hline Kelas & $\boldsymbol{X}_{\text {hitung }}$ & $\boldsymbol{X}_{\text {tabel }}{ }_{\text {Kab }}$ & Kriteria \\
\hline Eksperimen & 6,78 & 12,59 & Normal \\
Kontrol & 5,75 & 11,07 & Normal \\
\hline
\end{tabular}

Setelah dilakukan perhitungan, dilakukan kriteria pengujian, yaitu:

Jika $X_{\text {hitung }}^{2}>X^{2}$ tabel, maka distribusi data tidak normal; jika $X^{2}{ }_{\text {hitung }} \leq X^{2}{ }_{\text {tabel }}$, maka distribusi data normal.

Berdasarkan hasil perhitungan, dapat diamati bahwa nilai $X^{2}{ }_{\text {hitung }}=6,78$ dan $X_{\text {tabel }}^{2}=12,59$ berarti pada kelas eksperimen $X^{2}{ }_{\text {hitung }}<X^{2}$ tabel atau $6,78<12,59$, maka dapat dikatakan bahwa data posttest kelas eksperimen berdistribusi normal. 


\section{Uji Homogenitas Kemampuan Pemecahan Masalah Matematis}

Hasil perhitungan uji homogenitas data posttest kemampuan pemecahan masalah matematis siswa menggunakan uji $\mathrm{F}$, nilai varians sampel dan jumlah sampel dapat dilihat di lampiran dan disajikan pada tabel 6 sebagai berikut:

Tabel 6. Uji Homogenitas Kemampuan Pemecahan Masalah Matematis

\begin{tabular}{ccc}
\hline $\begin{array}{c}\text { Nilai Varians } \\
\text { Sampel }\end{array}$ & $\begin{array}{c}\text { Perbedaan Nilai Posttest } \\
\text { Kelas } \\
\text { Eksperimen }\end{array}$ & $\begin{array}{c}\text { Kelas } \\
\text { Kontrol }\end{array}$ \\
\hline $\boldsymbol{S}^{\mathbf{2}}$ & 129,73 & 124,32 \\
$\boldsymbol{N}$ & 38 & 38 \\
\hline
\end{tabular}

Menghitung varians terbesar dan terkecil:

$$
F_{\text {hitung }}=\frac{\text { varians terbesar }}{\text { varians terkecil }}=\frac{129,7321}{124,3225}=1,04
$$

Dari tabel uji homogenitas varians terbesar adalah kelas eksperimen, maka $d b_{\text {pembimbing }}=n-$ $1=38-1=37$, dan varians terkecil adalah kelas kontrol, maka $d b_{\text {penyebut }}=n-1=38-1=37$, dan taraf signifikan $(\propto)=0,05$, maka diperoleh $F_{\text {tabel }}=1,69$. Berdasarkan kriteria pengujian $1,04<1,69$ atau $F_{\text {hitung }} \leq F_{\text {tabel }}$, maka dapat disimpulkan varians-varians adalah homogen.

Tabel 7. Rekapitulasi Persentase Kemampuan Pemecahan Masalah Matematis

\begin{tabular}{lcc}
\hline Kategori & \multicolumn{2}{c}{ Presentase } \\
& $\begin{array}{c}\text { Kelas } \\
\text { Eksperimen }\end{array}$ & $\begin{array}{c}\text { Kelas } \\
\text { Kontrol }\end{array}$ \\
\hline Tinggi & 36,84 & 21,00 \\
Sedang & 50,00 & 52,70 \\
Rendah & 13,16 & 26,30 \\
\hline
\end{tabular}

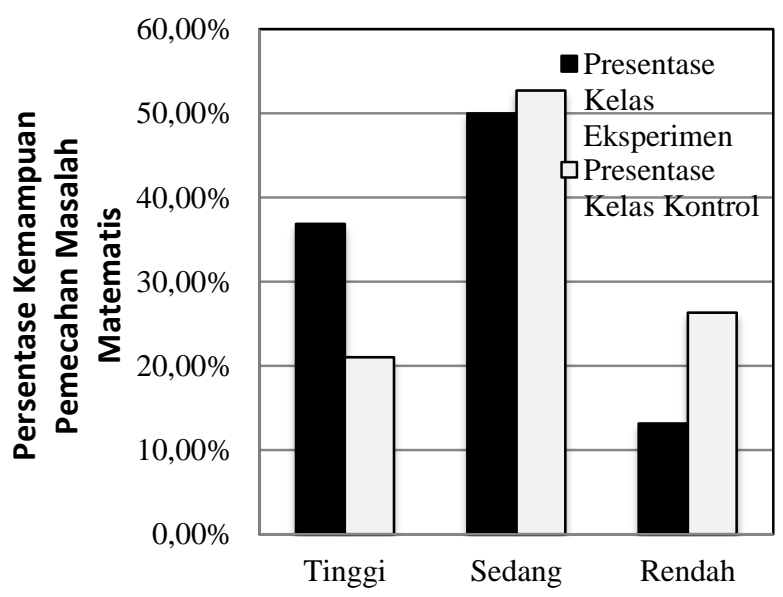

Gambar 3. Rekapitulasi Persentase Kemampuan Pemecahan Masalah Matematis
Berdasarkan tabel 7 terlihat siswa yang termasuk kategori tinggi berjumlah 8 orang dengan persentase $21 \%$, siswa yang masuk kategori sedang berjumlah 20 orang dengan persentase $52,7 \%$, siswa yang masuk kategori rendah berjumlah 10 orang dengan persentase 26,3\%. Analisis data tes siswa menunjukkan bahwa mean kemampuan pemecahan masalah matematis siswa yang diterapkan metode tutor sebaya yaitu $74,89 \%$ berbeda dari mean kemampuan pemecahan masalah matematis siswa yang diterapkan pembelajaran langsung yaitu 68,68 $\%$. Hal ini berarti perlakuan yang diberikan kepada kelas eksperimen memberikan pengaruh yang positif terhadap kemampuan pemecahan masalah matematis siswa kelas eksperimen lebih baik daripada kelas kontrol.

\section{Uji-t}

Uji-t ini dilakukan untuk melihat ada atau tidaknya perbedaan kemampuan pemecahan masalah matematis antara siswa yang mengikuti pembelajaran metode tutor sebaya dengan siswa yang mengikuti metode pembelajaran langsung. Setelah dilakukan uji analisis dengan uji-t diperoleh $t_{\text {hitung }}=2,05$. Dengan $d k=74$ dan taraf signifikan $5 \%$ atau 0,05 , maka diperoleh $t_{\text {tabel }}=1,99$. Berdasarkan perhitungan, diketahui bahwa $t_{\text {hitung }}>t_{\text {tabel }}$ yaitu 2,05 $>1,99$, sehingga dapat disimpulkan bahwa terdapat perbedaan kemampuan pemecahan masalah matematis antara siswa yang mengikuti pembelajaran metode tutor sebaya dengan siswa yang mengikuti metode pembelajaran langsung.

\section{Uji ANOVA Dua Jalur}

Analisis dengan menggunakan uji ANOVA dua jalur ini dilakukan untuk melihat ada tidaknya perbedaan kemampuan pemecahan masalah matematis antara siswa kedua kelas jika ditinjau dari kemampuan awal matematis; dan untuk melihat ada tidaknya perbedaan kemampuan pemecahan masalah matematis antara siswa yang diterapkan pembelajaran langsung.

Kriterianya terdapat perbedaan kemampuan pemecahan masalah matematis jika ditinjau dari kemampuan awal matematis antara siswa kelas eksperimen yang diterapkan metode tutor sebaya dengan siswa kelas kontrol yang diterapkan pembelajaran langsung jika $F_{\text {hitung }}>F_{\text {tabel }}$. Setelah dilakukan perhitungan uji ANOVA dua jalur maka diperoleh dua interpretasi pada tabel 8. Setelah dilakukan perhitungan uji ANOVA dua jalur ini diperoleh tiga interpretasi yang dapat dilihat pada Tabel 3.

1. Untuk metode pembelajaran, harga $F_{\text {hitung }}>$ $F_{\text {tabel }}$ yaitu 7,88 $>3,13$, maka $H_{0}$ ditolak. Hal ini berarti terdapat perbedaan antara metode pembelajaran terhadap 
Tabel 8. Hasil Uji ANOVA Dua Jalur

\begin{tabular}{lcccccc}
\hline \multicolumn{1}{c}{ Sumber Variasi } & Dk & $\begin{array}{c}\text { Jumlah } \\
\text { Kuadrat }\end{array}$ & $\begin{array}{c}\text { Mean } \\
\text { Kuadrat }\end{array}$ & $\mathbf{F}_{\text {Hitung }}$ & $\mathbf{F}_{\text {Tabel }}$ & Kesimpulan \\
\hline Metode Pembelajaran (A) & 2 & 8289 & 4144,5 & 7,88 & 3,13 & $H_{0}$ ditolak \\
KAM (B) & 1 & 2672 & 2672 & 5,08 & 3,98 & $H_{0}$ ditolak \\
Interaksi (A x B) & 2 & -21769 & -10884 & $-20,68$ & 3,13 & $H_{0}$ diterima \\
Dalam & 70 & 368502 & 5264,3 & & & \\
\multicolumn{1}{c}{ Total } & 75 & 10876 & & & & \\
\hline
\end{tabular}

2. Untuk KAM, harga $F_{\text {hitung }}>F_{\text {tabel }}$ yaitu 5,08 $>3,98$, maka $H_{0}$ ditolak. Hal ini terdapat perbedaan kemampuan pemecahan masalah matematis jika ditinjau dari kemampuan awal matematis.

Pada hipotesis pertama, berdasarkan hasil analisis uji-t diperoleh $t_{\text {hitung }}=2,05$ dengan $d k=74$ dan taraf signifikan $5 \%$ atau 0,05 , maka diperoleh $t_{\text {tabel }}=1,99$. Berdasarkan perhitungan, diketahui bahwa $t_{\text {hitung }}>t_{\text {tabel }}$ yaitu 2,05 $>1,99$ maka $H_{a}$ diterima $H_{0}$ ditolak. Hal ini berarti terdapat perbedaan kemampuan pemecahan masalah matematis antara siswa yang mengikuti pembelajaran metode tutor sebaya dengan siswa yang mengikuti metode pembelajaran langsung. Hal ini sesuai dengan penelitian yang pernah dilakukan oleh Iskandar Zulkarnain dan Rospala Hanisah Yukti Sari dengan judul "Pengaruh Model Pembelajaran Kooperatif Tipe Peer Lesson terhadap Kemampuan Pemecahan Masalah Matematis Siswa SMK Kelas X Banjarmasin" penelitian ini menyimpulkan bahwa terdapat perbedaan kemampuan pemecahan masalah matematis siswa antara menggunakan model pembelajaran kooperatif tipe peer lesson dan pembelajaran kooperatif[16].

Analisis data tes siswa diatas menunjukkan bahwa mean kemampuan pemecahan masalah matematis siswa yang mengikuti pembelajaran metode tutor sebaya yaitu 74,89 berbeda dari mean kemampuan pemecahan masalah matematis siswa yang mengiktui pembelajaran langsung yaitu 68,68. Hal ini berarti perlakuan yang diberikan kepada kelas eksperimen memberikan pengaruh positif terhadap kemampuan pemecahan masalah matematis siswa.

Pada hipotesis kedua, berdasarkan perhitungan pengujian dengan uji ANOVA dua jalur untuk melihat perbedaan kemampuan pemecahan masalah matematis siswa ditinjau dari kemampuan awal matematis siswa diperoleh, untuk kolom (antar tingkat kemampuan awal matematis), harga $F_{\text {hitung }}>F_{\text {tabel }}$ yaitu $7,88>3,13$. Untuk baris (antara kelas eksperimen dan kelas kontrol), harga $F_{\text {hitung }}>F_{\text {tabel }}$ yaitu $5,08>3,98$. Hal ini berarti terdapat perbedaan kemampuan pemecahan masalah matematis antara siswa yang mengikuti pembelajaran metode tutor sebaya dengan siswa yang mengikuti metode pembelajaran langsung, jika ditinjau dari kemampuan awal matematis siswa. Hal ini sesuai dengan penelitian yang dilakukan oleh Sri Adi
Widodo, Pardimin, dan Indriyti Eko Purwaningsih dengan judul "Pengaruh Media Komik terhadap Kemampuan Pemecahan Masalah dan Prestasi Belajar Matematika ditinjau dari Kemampuan Awal Siswa Kelas VII" penelitian ini menyimpulkan bahwa hasil penelitian menunjukkan media komik yang digunakan berpengaruh terhadap kemampuan pemecahan masalah dan prestasi belajar, ada perbedaan kemampuan awal dan prestasi belajar siswa kelas VII ditinjau dari kemampuan awal siswa, dan tidak ada interaksi antara media pembelajaran dan kemampuan awal terhadap kemampuan memecahkan masalah dan prestasi belajar matematika kelas VII [17].

\section{KESIMPULAN}

Berdasarkan hasil penelitian dapat diambil kesimpulan bahwa terdapat perbedaan kemampuan pemecahan masalah matematis antara siswa yang mengikuti pembelajaran metode tutor sebaya dengan siswa yang mengikuti metode pembelajaran langsung; dan terdapat perbedaan kemampuan pemecahan masalah matematis antara siswa yang mengikuti pembelajaran metode tutor sebaya dengan siswa yang mengikuti metode pembelajaran langsung, jika ditinjau dari kemampuan awal matematis siswa.

\section{DAFTAR PUSTAKA}

Heris Hendriana, Euis Eti Rohaeti, Utari Sumarmo. (2017). Hard Skills dan Soft Skills Matematika Siswa. Bandung: Refika Aditama

Herman Hudojo. (2005). Pengembangan Kurikulum dan Pembelajaran Matematika. Surabaya: UM Press

Zubaidah Amir MZ, Wahyudin, Turmudi. 1st International Conference of Mathematics and Science Education (ICMSEd 2016). Metacognition Think Aloud Strategies In Setting Cooperative Think-Pair-Share/Square to Develop Students' Math Problem Solving Ability. Advances in Social Science, Education and Humanities Research (ASSEHR). Volume 57. Atlantis Press

Zubaidah Amir MZ. (2014). Strategi Metakognitif: Suatu Kajian Penerapannya dalam Pembelajaran Matematika. Prosiding 
Seminar Nasional Pendidikan Matematika FKIP-Uninus. ISBN: 978-602-7648-05-0

Risnawati. (2013). Keterampilan Belajar Matematika. Yogyakarta: Aswaja Pressindo

Zubaidah Amir. (2010). The Implementation of Mathematics Teaching with Open Ended Approach to UIN SUSKA RIAU Matematics Student's Ability of Mathematical Creative Thinking. Proceedings of the International Seminar on Mathematics and Its Usage in Other Areas. ISBN. 978-979-1222-95-2

Suherman, dkk. (2003). Strategi Pembelajaran Kontemporer. Bandung: JICA

Leni Reziyusthika. (2017). Pembelajaran Kooperatif dengan Pendekatan Tutor Sebaya untuk Meningkatkan Hasil Belajar pada Mata Kuliah Aljabar Linear Mahasiswa Informatika. Jurnal Penelitian Pendidikan dan Pengajaran Matematika. Volume 3 Nomor 2

Erman Suherman, dkk. (2001). Strategi Pembelajaran Kontemporer. Bandung: JICA UPI

Syaiful Bahri Djamarah, Aswan Zain. (2006). Strategi Belajar Mengajar. Jakarta: Rineka Cipta

Hisyam Zaini, dkk. (2012). Strategi Pembelajaran Aktif. Yogyakarta: CTSD

Muhibbin Syah. (2006). Psikologi Pendidikan dengan Pendekatan Baru. Bandung: PT. Remaja Rosdakarya

Dewi Purwaningrum dan Sumardi. (2016). Efek Strategi Pembelajaran ditinjau dari Kemampuan Awal Matematika terhadap Hasil Belajar Matematika Kelas XI IPS. Jurnal Manajemen Pendidkan. Magister Administrasi Pendidikan Sekolah Pascasarjana UMS. Volume 11 Nomor 2. ISSN: 1907- 4034

Karunia Eka Lestari \& Muhammad Ridwan Yudhanegara. (2017). Penelitian Pendidikan Matematika. Bandung: PT Refika Aditama

Sugiyono. (2014). Metode Penelitian Kuantitatif, Kualitatif, dan $R \& D$. Bandung: Alfabeta

[16]

Iskandar Zulkarnain, dkk. (2015). Pengaruh Model Pembelajaran Kooperatif Tipe Peer Lesson terhadap Kemampuan Pemecahan Masalah Matematis Siswa SMK Kelas X. Jurnal Edumatica. Volume 3 Nomor 2

[17]

Sri Adi Widodo, Pardimin, dan Indriyti Eko Purwaningsih. (2015). Pengaruh Media Komik terhadap Kemampuan Pemecahan Masalah dan Prestasi Belajar Matematika ditinjau dari
Kemampuan Awal Siswa Kelas VII, Jurnal Teknologi Pendidikan, Volume 1 Nomor 2 ISBN. 978-602-73403 